\title{
Imitation of Metatheater \\ In Theocritus 15, Herodas I And Virgil Eclogues 3
}

\author{
Prof. Ophelia Fayez Riad \\ Faculty of Arts- Cairo University
}

\section{Introduction:}

The etymology of metatheatre (from the Greek prefix 'meta', which implies 'a level beyond' the subject that it qualifies), metatheatricality is generally agreed to be a device whereby a play comments on itself, drawing attention to the literal circumstances of its own production, such as the presence of the audience or the fact that the actors are actors, and/or the making explicit of the literary artifice behind the production. Some critics use the term to refer to any play which involves explicit 'performative' aspects, such as $\underline{\text { dancing, singing, or role-playing by onstage characters. }}{ }^{(1)}$ Katheryn Gutziller refers to the superiority of Comedy to depict the real life. She offers discussion of select Menandrean passages, organized under the rubric of four figures of metatheatrical play commonly in ancient drama: Direct reference to staging or performance, tragic quotations and parallels, allusion to technical dramatic terminology, and use of disguise and deceit. ${ }^{(2)}$ Also Lisa Maurice in her "Examination of a double motif in Plautus" , she explains that Metatheatricality is the conscious underscoring of the play as a play, whereby drama makes reference to itself as drama. With this 
approach, the audience is encouraged to view the play on two levels, both as a pretence of reality and also as an unreal piece of dramatic fiction. ${ }^{(3)}$ As one scholar recently put it, metatheater is:" Drama within drama as well as drama about drama."(4)

But Richard Hornby concludes the metadrama by dividing it in four important categories: The play within the play, the ceremony within the play, Role-playing within the role, literary and real life reference within the play. ${ }^{(5)}$

Theocritus (310 B.C.) and Herodas (240 B.C.) were influenced by both the mimic and the comic traditions. In Herodas we recovered one of the leading representatives of an important branch of Greek literature, the Mime, which had been known to us mainly from certain pieces of Theocritus.

The Mimes consist of short dialogues in verse, depicting scenes from everyday life. They are "tableaux de genres", drawn from personal observation. They are written in the language of the common people, with its colloquialisms, vulgarisms, and a large number of proverbs. The two poets, Herodas and Theocritus, besides their personal observation, have drawn from literary sources notably Sophron and Aristophanes. ${ }^{(6)}$

In Idyll xv, Theocritus gives a description of a day in Alexandria spent by two Syracusans dames in visiting the Adonis feast. In this idyll, Theocritus has made innovations of an important character: First, he has changed the scene twice, the piece being divided into three acts, of which the first takes place in the house of Praxinoa, the second in the street, the third in the king's palace. Second: The number of the characters is greater than usual. Besides 


\section{Ophelia Fayez Riad}

Praxinoa, Eunoa (her slave), Gorgo (her visitor), we have an old woman and two strangers. The number of characters in a Mime is as rule not more than three. These three pieces thus show the same return to nature as the bucolic poems. He has added to each a delicacy and refinement of treatment, and a beauty of expression all his own. We mention the hot temper of Praxinoa in the pleasure which the poetry gives us. Moroever, the use of the hexameter is a clear proof that Theocritus treated the Mime from the point of view of a poet. In a word, realism in the Mime as used by Theocritus, is tempered by poetic feeling. ${ }^{(7)}$

In particular, Theocritus has wedded the dramatic form and dialect of the $5^{\text {th }}$ century mime writer Sophron to the hexameter of epic, while Herodas has joined the same form to the dialect and meter of the $6^{\text {th }}$ century poet Hipponax. Both poets were interested in the quasi- dramatic effects possible when dramatic and non-dramatic elements are combined in one work. The term "quasi-dramatic" is often used to describe something that fails as drama. In short, it succeeds in simulating dramatic effects in a non-dramatic context.

Stanzel concluded in his article ${ }^{(8)}$ that the idylls and mimes, while displaying dramatic features, were designed for an audience not of spectators, but of listeners or readers familiar with the theater.

\section{Imitation of Metatheater in Theocritus, Herodas and Virgil:}

Theocritus and Herodas imitate the dramatic technique of metatheater, whereby members of the audience are made aware, if only for a moment, that they are participating in something artificial and illusory. As in the theater, this quasi-dramatic technique serves to $1 \pi$ 
heighten the enjoyment of participating in an illusion.

In the middle of idyll 15, Gorgo and Praxinoa view royal tapestries at the festival of Adonis. They comment on the beautiful realism of drawn images: (11.78 - 83)

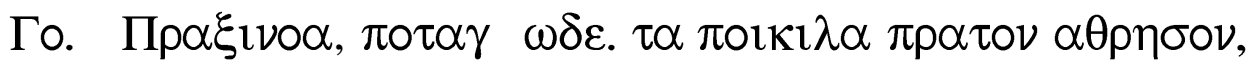
$\lambda \varepsilon \pi \tau \alpha \kappa \alpha l \omega \varsigma \chi \alpha \rho 1 \varepsilon v \tau \alpha \cdot \theta \varepsilon \omega \nu \pi \varepsilon \rho \circ \nu \alpha \mu \alpha \tau \alpha \phi \alpha \sigma \varepsilon 1 \varsigma$. ПР. $\pi \circ \tau \nu \mathrm{l} \quad \mathrm{A} \theta \alpha \nu \alpha 1 \alpha, \pi \circ 1 \alpha \mathrm{l} \sigma \phi \varepsilon \pi \circ \nu \alpha \sigma \alpha \nu \varepsilon \pi \mathrm{l} \theta \mathrm{ol}$,

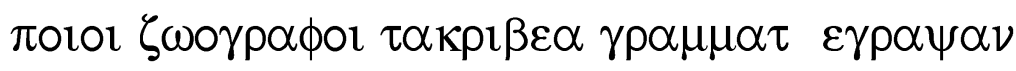
$\omega \varsigma \varepsilon \tau \cup \mu \varepsilon \sigma \tau \alpha \kappa \alpha \nu \tau \imath \kappa \alpha l \omega \varsigma \varepsilon \tau v \mu \varepsilon v \delta 1 v \varepsilon v \nu \tau l$,

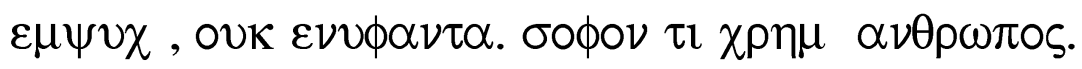

" Gorgo: Come here, Praxinoa. Look first at these embroidered works, so fine and graceful; you'd say they were clothes for the gods.

Praxinoa: Lady Athena, what weavers that labored over them, what illustrators that drew the exacting figures!

How natural they stand and how natural they whirl aboutAlive, they are, not woven. Man's a clever thing."(9)

Gorgo and Praxinoa praise the tapestries for their artistry and realism, Theocritus seems to suggest that his poem, like the

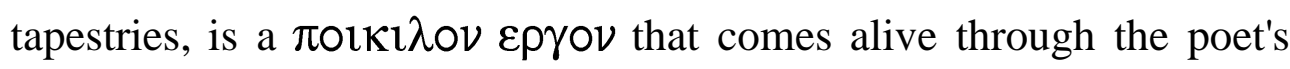
artistry. His audience is thus invited to connect the artistic representation of nature in the tapestries with the poetic representation of the characters within the work. ${ }^{(10)}$

At this moment, as Theocritus establishes the connection between the realistic tapestries and his own mimetic art, he also draws 
attention to the artificiality of his composition. As Gorgo and Praxinoa continue praising the tapestries, a man rudely interrupts them: (11. 8788)

$\Pi \alpha v \sigma \alpha \sigma \theta, \omega \delta v \sigma \tau \alpha \nu 01, \alpha v \alpha \nu v \tau \alpha \kappa \omega \tau \imath \lambda \lambda 01 \sigma \alpha 1$,

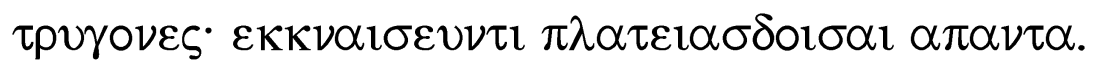

" Wretched women, stop your endless twittering.

Turtle- doves! They'll wear you out with all those broad vowels." (11)

A man tells them rudely to stop chattering in their annoying Doric, while speaking in the same artificial dialect. He criticizes them not only for being long-winded, but for the dialect they speak: Their Doric, which makes everything too broad. The function of his speech seems at first to be comic relief, emphasizing the light characterization of Gorgo and Praxinoa throughout as chatterboxes. ${ }^{(12)}$ But instead of focusing on the women's broad-vowels babbling, Praxinoa's reaction to the man's outburst invites us to scrutinize the peculiarity of his own speech:

(11. 89-93):

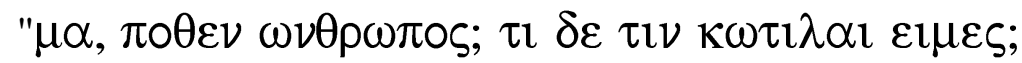
$\pi \alpha \sigma \alpha \mu \varepsilon v \circ \varsigma \varepsilon \pi \imath \tau \alpha \sigma \sigma \varepsilon \cdot \Sigma v p \alpha \kappa o \sigma l \alpha 1 \varsigma \varepsilon \pi \imath \tau \alpha \sigma \sigma \varepsilon l \varsigma$.

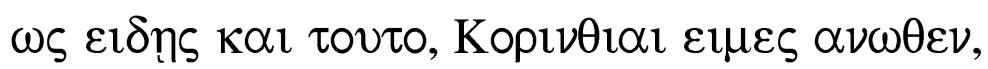

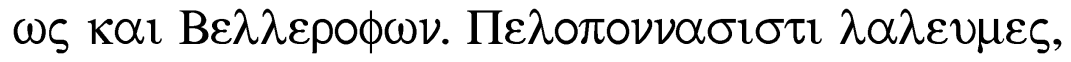
$\Delta \omega p 1 \sigma \delta \varepsilon \nu \delta \varepsilon \xi \varepsilon \sigma \tau \imath, \delta \circ \kappa \omega, \tau 01 \varsigma \Delta \omega p \imath \varepsilon \varepsilon \sigma \sigma 1$. 
My, where's that from? And what's it to you, if we do "twitter"?

Give orders to those you own - you're ordering around Syracusans.

And know this too, please: we're Corinthians by descent,

Just like Bellerophon. We chatter in Peloponnesian, and it's permitted for Dorians to speak Doric." (13)

It would be logical to assume from the man's criticism of the women's Doric that he is not a Dorian. ${ }^{(14)}$ Nevertheless, his dialect is the same as that of Gorgo and Praxinoa. As Praxinoa says, it is permitted ( $\varepsilon \xi \varepsilon \sigma \tau 1,93)$ for Gorgo and her to speak Doric because they are Dorian, but this begs the question: Should the man be permitted to speak the same Doric?

In the tapestry passage, Theocritus makes the audience conscious

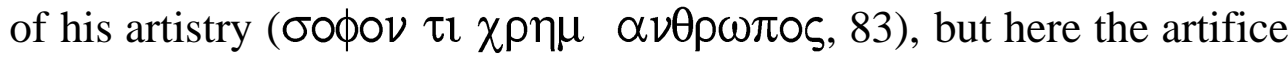
is at the forefront, in the uniform literary dialect he has chosen to employ. ${ }^{(15)}$

In Herodas Mimiambi I, an otherwise realistic threat to make a woman limp draws attention to the "limping" choliambic meter. Herodas' characters speak: A madam named Gyllis is attempting to persuade Metriche, a reformed prostitute, to come out of retirement and give up her loyalty to one man. Metriche's response is full of indignation. (11. 69-72):

$$
\text { " } \tau \alpha v \tau \quad \varepsilon \gamma \omega[\varepsilon] \xi \varepsilon \lambda \lambda \eta \varsigma
$$

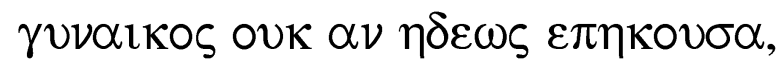
$\chi \omega \lambda \eta \nu \delta \alpha \varepsilon 1 \delta \varepsilon 1 \nu \chi \omega \lambda \alpha \nu \varepsilon \xi \varepsilon \pi \alpha 1 \delta \varepsilon v \sigma \alpha$ 


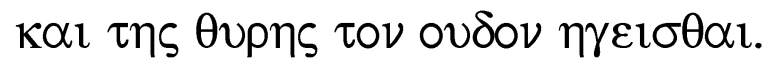

I would not have kindly listened through

to the end of this speech from another woman, but would have taught her to sing her lame song limping and to hate the very threshold of my door." (16)

While Metriche seems to display real anger, the lines contain a literary joke. Thus ( $\alpha \varepsilon 1 \delta \varepsilon \imath \nu \chi \omega \lambda \alpha 71)$, Metriche's threat to teach Gyllis to sing with a limp is at the same time a threat to teach her how to sing Hipponactian Choliambs. But Gyllis refers to sing a limping song while speaking in " limping choliambs" ( $\chi \circ \lambda \iota \alpha \mu \beta \circ 1)$.

Theocritus and Herodas are known to have borrowed much of their material from mimic and comic traditions. They also adopt comic techniques particularly designed to facilitate audience participate.

In Virgil's third eclogue, Damoetas, supposedly a shepherd, mentions Pollio Virgil's contemporary, as the reader (lectori 11. 84-85) (17) of his song. While Virgil's debt to Theocritus is clearly acknowledged through his chosen form and the quasi-dramatic nature of his work without having Damoetas break character completely. This technique is similar to that by which Theocritus and Herodas adapt metatheater to their own quasi-dramatic texts. In all three passages, therefore the acknowledgement of artifice reflects not a rupture with the dramatic tradition, but a continuing concern with producing dramatic effects for a new type of audience. 


\section{Poet-audience in Hellenistic Mime:}

The audience for comedy was accustomed to metatheatrical effects as a way of engaging actively with the dramatic illusion. The scenes in which Theocritus and Herodas appear to dismantle this carefully constructed illusion serve the same purpose: Praxinoa in idyll 15 and Metriche in Mime I never step out of character, and their emotional reactions to Gyllis and the Alexandrian stranger remain realistic. But the way the artifice is emphasized, and thus the way the audience participation in it, differs from comedy. Theocritus and Herodas do not draw attention to anything theatrical, but to the very meters and dialects they employ. It is not the actors who emphasize, either through audience address or references to the theatrical experience, but the poet themselves. Theocritus and Herodas can do this because they have intentionally diverged from normal dramatic practice in their choice of meter and dialect. Herodas has selected this un-dramatic meter for all his dramatic dialogues. So too Theocritus ' hexameter, which is unusual and always distinctive in drama, becomes norm.

We will call Theocritus idyll 15 11. 87-88 and Herodas Mime I 1. 71 instances of indirect audience address: It is the poet himself through indirect means. A passage in Virgil's third eclogue, which, like the Hellenistic passages, has traditionally been treated in isolation, bears a similar resemblance to metatheater. After Damoetas and Menalcas challenge one other to a singing contest and settle on prizes and a judge (11. 1-59). 
In the context of this dramatic action - a singing context between two shepherds- the reference to Pollio as lector represents another example of indirect audience address. Mentioning Pollio as lector makes Virgil's general audience conscious of the fact that they too are reading songs. The indirect audience address draws vivid attention to Virgil's literary imitation of a dramatic and oral act.

Finally, Theocritus and Herodas superimpose meters and dialects atypical

for drama upon their dramatic forms and implicitly ask their audiences to accept this as a new convention. They then adapt metatheater to their new creations to play with this convention. Virgil's further use of indirect address suggest that all three poets had similar audiences in mind: Readers and listeners with experience as spectators. Theocritus and Herodas evoke drama in a non-dramatic setting. Their indirect asides, like Virgil's blunt reference to a lector, serve to acknowledge the successful textual adaptation of a traditionally dramatic form. 


\section{The Notes:}

1- Abel Lionel, Metatheater: A New View of Dramatic Form, New York (1993).

2- Kathryn Gutziller," The Tragic Mask of Comedy: Metatheatricality in Menander"

Classical Antiquity, vol. 19, No.1 (April 2000), pp.102- 137.

3- Lisa Maurice, " Amici et Sodales: An Examination of a Double Motif in Plautus" Mnemosyne, Fourth Series, Vol. 56, Fasc. 2 (2003), pp.164-193; cf. Thomas G. Rosenmeyer: " Metatheater": An Essay on Overload" Arion, third Series, vol. 10, No.2 ( 2002), pp.87-119, the fictional content of the story is continually reflected by its formal existence as text, and the existence of that text within a world viewed in terms of textuality.

4- M. Ringer, Electra and the Empty Urn, Metatheater and Role Playing in Sophocles, Chapel Hill, (1998), p.7.

5- Richard Horby, Drama, Metadrama and Perception, Leurisburg P.A.: Bucknell (1986); cf. Thomas G. Rosenmeyer: op.cit., pp.87- 119, He explains the play within a play : It is the relation between illusion and fact, a relation that is prominent in detective drama where the sleuth or the reader is misled by scenes rendering false clues.

6- Herodas, The Mimes, ed. By J.Arbuthnot Nairn, Oxford, London (1904), p.XI,

7- Ibid., pp.xxiv-xxxv.

8- K.H. Stanzel, " Mimen, Mimepen und Mimiamben - Theokrit, Herodas und die Kreuzung der Gattungen." In Genre in Hellenistic Poetry, ed. By M.A. Harder, R.F. Regtuit and G.C. Wakker, Leuven (1998), pp.143- 165.

9- Ph.E. Legrand, Bucoliques Grecs, Les Belles letters, Paris (1925), 11. 78-93.

10- M. Skinner, " Ladies' Day at the Art Institute: Theocritus, Herodas and the Gendered Gaze" In Making Silence Speak: Women's Voices in Greek Literature and Society, ed. A. Lardinois and L. McClure, Princeton (2001), pp.201-222.

11- Legrand, op.cit., 11. 87-88.

12- J. Burton, Theocritus' Urban Mimes: Mobility, Gender and Patronage, Berkeley (1995), he argues that Theocritus portrays the stranger as rude to make the reader sympathize with Gorgo and Praxinoa.

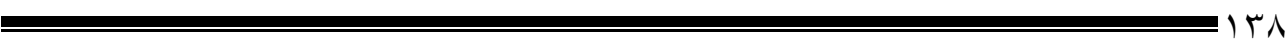


13- Legrand, op.cit., 11.89-93.

14- A.S.F. Gow, Theocritus, vol.2, Cambridge (1952), p. 290.

15- W.C. Hembold, " Theocritus 15.87-88" CP 46,p.116.

16- Herodas, op.cit., 11. 69-72.

17- Virgil, Eclogues, Georgics, Aeneid I-VI, trans. By H. Rushton Fairclough, LCL, London (1999), 11. 84-65. 